\title{
The School-Based Pesantren in Border State, An Alternative to Caracter Education for Children of Indonesian Migrant Workers?
}

\author{
Baequni $^{1}$, Suryadi ${ }^{2}$, Zaenab Hanim ${ }^{3}$ \\ baequnipik@gmail.com ${ }^{1}$, hsuryadi@gmail.com ${ }^{2}$, zaenab.hanim@gmail.com ${ }^{3}$ \\ Universitas Negeri Jakarta ${ }^{1,2}$, Universitas Mulawarman ${ }^{3}$
}

\begin{abstract}
The School-Based Pesantren Mutiara Bangsa is an implementation of community-based management system. It is perceived as one of the alternatives of dealing with border education issues. The focus of this study was the management of institution education what implement of integrated school with religious education units. This involved the educational role of an institution in Sebatik Nunukan District as a community-based structure supporting government's programs and helps tackle educational issues in border areas.This research used qualitative approach in case study method through data collection, in-depth interviews, participatory observation, and documentation. The Data were analyzed using Robert K. Yin analysis. The findings established that Mutiara Bangsa Islamic Boarding School was the right option in the border area considering increasing human resource needs of the society. In addition, it has a strategic role in the border area and serves as a tool for government programs implementation. Such programs are mainly character education, a sense of nationality providing learning services in the outermost, foremost, and disadvantaged areas, and an alternative education for the children of Indonesian Migrant Workers.
\end{abstract}

Keywords: Character education, Islamic Boarding School (pesantren), Children of Indonesian Migrant Workers. Sebatik Nunukan District, Indonesia.

\section{Introduction}

According to the 1945 Constitution, Republic of Indonesian Law No. 20 of 2003 on the National Education System, and Millenium Development Goals, there is need to ensure that the state is obliged to provide education to children without exception. The success of education depends on the ability and willingness of the government to provide easy access to education for citizens without discriminatory attitudes [1]. This includes the children of Indonesian migrant workers dropping out of school [2].

The education problems faced by children of immigrants is influenced by several issues including motivational factors for getting better jobs [3], economic difficulties [4], poverty responses from their area of origin [5], failure by the Malaysian government to provide secondary education for children who do not have IDs [6] lack of coverage in other 
plantation areas [7]. With this problems, Mutiara Bangsa Islamic Boarding School was established by community with assistence of the Indonesian government at the border areas of Nort Kalimantan and Malaysia. It accomodates some children dropping out of school from the East Malaysian oil palm plantations.

The main purpose of this school was to overcome the problem faced by the children of Indonesian migrant workersliving at the border areas of Indonesia and Malaysia (KJRI Sabah, 2018), as well as local children from Nunukan District.This situation also happens at the border areas of Mexico and America.Based on the reseach that adjusting household resources and household-level immigration experience, Mexican-born children in the United States as well as the U.S.-bornchildren in Mexico, particularly those who arrived recently, were left behind in schoolenrollment. For this reason, there is limited guidance for predicting how the duration of residence in these settings might beassociated with children schooling[8]. This research showed there was a problem with residence time of the immigrant children. The similar case took place at the border line of Canada and United Stated [9], and that cross-border schooling can tell usmuch about not only the history of schooling but also the identity, community, and culture among the people of Canada and the United States. At the very least it is a reminder about just how permeable the border is.

Based on findings about management in education, experts identified several perspektive. Education has to be implemented based on minimum service standards with the principle of school based management (SBM), a strategy that include inputs [10]. In the SBM framework, it is relevant to use "The Pyramid Model of School Management: Feedback-Based Management". This model describe the school's management triangle model, first, relating to feedback management in schools, that just as industrial organizations use three major management processes. It also involves managing school's resources effectively to transition to schools' autonomy. Besides, flexibility and creativity are needed, and the budget should also be in line with school's activities. In addition, schools need to consider other resources, teachers, administrative staff, and principals. Third, it also entails Process Management, both internal and external. Internal school processes include evaluation, development, administrative processes and others[11].the components in Quality Educational SBM include; Curriculum and teaching's Program Management, Education personnel, Student, Financial and financing, Facilities and infrastructure education, School relations with the community, special services managements[12].

The idea of implementation of school management oriented towards the quality of education can be conveyed by several principles. Firstly, it can be by continuous improvement,with the understanding that educational institutions do continuous improvements to ensure the components of education achieve the standards set. Secondly, it can be through determining quality standards. This means all components should meet quality standards. Thirdly, it can be done through cultural change, meaning that all components have awareness in maintaining quality and improve the value of learning. The fourth one is organizational change, meaning if there is an alteration of vision, 
mission, and objectives of educational institutions, there should be changes in structure and authority as well as work relationships that lead to quality improvement. Fifth, maintaining customer relationships requires institutions to have a good relationship with the customer in order to acquire input on the organization of education so that the quality of learning can be maintained[13]. Effective schools can be realized if managers develop some of the items commonly used in most effective institutions of learning. These include responsibility-oriented leadership; hierarchical and democratic decision making; involvement of key stakeholders in school programs; proper distribution of resources, whether physical, financial or personnel; curriculum implementation; develop environment, climate, and culture. These factors provide opportunities for the school community to move forward and be valuable; as well as opening communication among the citizens of the school.(14).

Islamic Boarding School is an educational model established with the arrival of Islamic teachings to Indonesia and in the legacy of pre-Islamic society (Hindu-Buddhist), which in certain stages changed the content of religious teachings. became the teachings of Islam, and it became the origin of the formation of boarding school system in Indonesia[15]; Basically Islamic boarding school has received recognition as intelligence and development agent functioning as an institution of social and economic education [16].Islamic boarding school identification has several advantages. The notable ones include: (1) success in obtaining autonomy. (2) Having strong peer integrity supported by parents. (3) Ability to build relationships with others [17];supporting the effectiveness of character education in improving academic independence. The students in boarding schools have a higher expectation of success than their fellows in general[18]. This shown in the following ways; (1) young disadvantaged people are able to lead them in meeting social needs, and better culture, (2)increased chances of cultural gain, (3) prevention noise, (4) can be a companion of several learners, (5) many students, (6) social development, (7) strengthening the relationship ties and cultural identity, (8) neutralized status of the elite, (9) development leadership skills, and (10) Understanding social stratification [19]; 20].

\section{Methodology Research}

The Research used qualitative approach in case study method, especially in data collection, using four field activities including interviews; observations; collection and examinations. The resarcher used data analysis in four aspects, compiling, disassembling, reassembling, interpreting and concluding[21]. The study was conducted from October 2015 to 2016 at the Mutiara Bangsa Islamic Boarding School, a non-governmental organization established in 2003 based on Notarial deed Chairu Subhan No. 23 of 2007 dated November 8, 2007.The data collected was for identification of: (1) information on the establishment of Mutiara Bangsa's Islamic Boarding School, including the existence of children of Indonesian Migrant Workers and pupils from Nunukan District, (2) the role of this educational Institution in the region. (see at https://osf.io/ju6f4) 


\section{Result and Discussion}

From the data analysis, the establishment of school-based pesantren of Mutiara Bangsa had several goals;

\subsection{Integrating Education Support.}

The educational management by Mutiara Bangsa often receive formal support from the Ministry of Religion, Education and Social Affairs, as well as community tenacity and interests. The implementation of the Mutiara Bangsa program is achieved by means of a strong network that allows its growth into an educational institution implementing government programs in the outermost, foremost and disadvantaged regions, including character education programs.In general, private schools mostly get support from the community while public schools are often aided by the government. However, the establishment of Mutiara Bangsa was largely supported by the government, even though it was private.The uniqueness of this institution is brought by the fact it was different compared to other educational establishments in East and northern Kalimantan.

The implementation of education in Mutiara Bangsa Islamic boarding school provide opportunities for students to develop characters such asreligiousness, honesty, tolerance, discipline, hard work, independence, creativity, Democratic, a sense of nationalism, friendliness, caring for others as well as the environment, social sensitivity, simplicity and love science. This is made possible since the system of integration of pesantren and schools creates a school culture through: habituation of students; the values that apply in the pesantren, the example of the educator, togetherness in the school environment, and the norms and regulations that apply in school

\subsection{An Alternative Education Services in Border State.}

Sebatik, actually, has several categories of educational units including Islamic Elementary, Secondary, and High Schools, all of them being private schools. Even though there are many schools and learning centers with state status, Mutiara Bangsa has outstanding characteristics. This is attributed to the fact that it is in form of a school as well as a pesantren whose students occupy dormitories in a boarding school environment. With this feature, the pearl of the nation becomes a new pattern of education.

In the light of the above, an education integrating the Islamic Boarding School system will have a positive impacts to students. That is why it is recommendable to have educational institutions integrated with Islamic Boarding School. Empowering communities in the areas through education will help deal with limitations that comes with distance, time, means, and access. This issues can be reduced and as a result, more people in the location will be qualified and will offer various choices to the interest of the community in the outermost, foremost, and disadvantaged areas.

Alternative education services for the Children of Immigrants, as factually schoolage children in some oil palm plantations in Malaysia, have not received a variety of 
necessary services. The presence of Islamic Boarding School MutiaraBangsa offers an appropriate alternative to these children workers.

\subsection{Obstacles Mutiara Bangsa Islamic Boarding School.}

Mutiara Bangsa as an educational legal entity organizing pesantren-based schools faces the following constraints and obstacles: (1) a high dependence on government assistance, both the Indonesian and the regional government one; (2) the existence of conflicts that the influence leadership at the local level; (3) the perception that it is an educational institution for immigrants and that the community and local government lack ownership; (4) there is still inadequate facilities (5) the choice of the principles of education has not been adopted by the management, (6) lack of a productive business unit to support the independence of institutional funding; (7) changes in operational policies mainly concerning the burden of student contributions, and (8) student input that is still not standardized, hampering the achievement of higher competency programs.

\section{Conclusion and Recommendation}

This study concludes that: (1) The establishment of the Mutiara Bangsa educational institution is an embodiment of the government's program through several ministries as well as the desires of the Indonesia-Malaysia border community, Sebatik, Nunukan Regency. (2) In implementing the educational program, there was formation of a school-based pesantren. (3) through a school-based pesantren system, access to education for children of the Indonesian workforce, and those in the foremost, outermost and disadvantaged areas is easier, both in terms of time, place, distance and infrastructure. Moreover, the students get character education.

Therefore, this school-based pesantren can be supported through the following recommendations: (1) for Mutiara Bangsa institutions to be oriented towards national education standards, there should be an effective management, enhanced quality of education services and improve internal constraints, (2) for the government to provide a substantive support to Mutiara Bangsa educational institutions and help them achieve independence,(3) for the community's benefit, participation should be more intense in various forms.

\section{References}

[1]Stalker, P.: Kita Suarakan MDGs Demi Pencapaiannya di Indonesia, Cetakan Pertama, Jakarta: Bappenas Republic of Indonesia (RI). (2007)

[2] Sulong, J.: Pondok Education In Seberang Perai: Its Evolution and Uniqueness. Kajian Malaysia. Vol. 33, Supp. 2. Universiti Sains,Malaysia. pp. 75-90 (2015)

[3]Jacqueline L. Joudo.: Andrevski Hannah and Lyneham Smantha. 2013. Experience of Trafficed persons : And Indonesian Sample. Trends \& Issues In Crime and Criminal Justice, Australian Government Australian Institute of Crimonologi, No. 449 May (2013) 
[4] Liow Joseph.:Malaysia's Illegal Indonesian Migrant Labour Problem : In search solutions.Contemporary Southeast Asia; Social Science Databest, April, 25,1, p.44. (2003)

[5] Sukoco, 2018. 50.000 Anak TKI di Tawau Malaysia Tak Punya Kartu Identitas. Kompas.com, April, 27, $2017 \quad$ [Online] Avialable https://regional.kompas.com/read/2017/04/27/09034711, [Accessed : Maret, 14, 2018.

[6] Tuatul Mahfud. 2011. Realita "Education for All” di Negeri Sabah. wordpress.com, [Online] Available : , [Accessed : November 12, 2011]

[7] Desy Anastasia Christie. .Upaya Indonesia Dalam Menangani Pendidikan Tenaga Kerja Indonesia di Sabah Malaysia. Journal Ilmu Hubungan Internasional, 4 (4) 11611176. 2016

[8] Glick. E. Jennifer and Yabiku T. Scott.: Migrant children and migrants' children: Nativity differences in school enrollment in Mexico and the United States. Demographic Research: Volume 35. Article 8. Research Article(2017)

[9] Anthony Di Masci. . Cross-bordEr sChooling and thE Complexity of Local Identities in The Quebec-Vermont Borderland Region: A Historical Analysis. journal of eastern townships studies. School of Education Bishop's University(2018)

[10] Syaiful Sagala, . Manajemen Berbasis Sekolah dan Masyarakat Strategi Memenangkan Persaingan Mutu, PT. Cetakan Pertama, PT. Jakarta: Nimas Multima. (2004)

[12] Mulyasa E. . Manajemen Berbasis Sekolah Konsep, Strategi dan Implementasi, Cetakan ke-12, PT. Bandung: Remaja Rosdakarya (2009)

[13] Tony Townsend.: Effective Schooling for The Community Core-Plus Education, (Routledge, London, ) (1994)

[14] Sallis Edward.: Total Quality Management in Education Manajemen Mutu Pendidikan, terjemahan Ahmad Ali Riyadi dkk, cetatakn VIII Jogyakarta: IRCiSod. 2008

[15] Ismail, Syamsul Bachri Thalib, Sulaiman Samad, Ramlan Mahmud. . The Development of Character Education Model to Improve Students academic independence in islamic boarding school in sinjai District, Indonesia. The New Educational Reviewe, DOI: 10.15804/tner.2016.46.4.02, 20162016

[16] Rahardjo. M. Dawam.:Pesantren dan Pembaharuan, Cetakan ke-5. Jakarta: Pustaka LP3ES Indonesia (2002)

[17] Pfiffer, 2013) [20];Jens P Pfeiffer and Martin Pinquart. 2017. Alcohol use among students from boarding schools in comparison to students from day schools. Int $J$ Child Adolesc Health 2017;10(3):315-323 ISSN: 1939-5930 (C) Nova Science Publishers, Inc., 2017.

[18] Allison Steel.: Estimates of Enhanced Outcomes in Employment, Income, Health, and Volunteerism for The Association of Boarding Schools Member School Graduates, Journal of Advanced Academics. Vol. 26(3) (2015)

[19] Graham Abigail Gundlach.: Power of Boarding Schools a Historiographical Review. American Educational History Journal. Volume 39, Number 2, pp.467-481 (2014)

[20] Lira L. Bass.: Boarding Schools and Capital Benefits:Implications for Urban School Reform. The Journal of Educational Research, Routledge Taylor and Francis Group, ISSN:0022-0671 print/1940-0675 online, 107:16-35 (2014)

[21] Robert K. Yin.: Qualitative Research From Start to Finish. Newyork: The Guilford Press (2011) 